\title{
Analisis Nilai Tambah dan Usaha Pengolahan Tepung Sukun Sebagai Upaya Peningkatan Pendapatan Petani
}

D 0 I:10.18196/ agr.2233

\begin{abstract}
Bread fruit processing into flour is an alternative way of processing which is has several advantages including; increase the shelf life, facilitate the process of raw materials and increase the selling price, while its nutrient is relatively unchanged. The purpose of this study is to examine the amount of value added product generated by bread fruit flour and to determine business analysis of bread fruit flour in Kepulauan Seribu, DKI Jakarta Province. Data is collected using interviews, observation and mutilation. Measurement is done by calculating the value added products resulting from the processing of bread fruit into bread fruit flour, while analysis of feasibility is calculated based on the analysis of profit and analysis of revenue and costs as well as the $\mathrm{R} / \mathrm{C}$ ratio. Breadfruit flour business has gave
\end{abstract}

product value added, profit and $\mathrm{R} / \mathrm{C}$ ratio account Rp. 5,500 per kilogram, Rp. 218,000 and 1.57 respectively.

Keywords: added value, breadfruit, $\mathrm{R} / \mathrm{C}$ ratio

\section{INTISARI}

Pengolahan sukun menjadi tepung merupakan alternatif cara pengolahan yang memiliki beberapa keunggulan, yaitu meningkatkan daya simpan, memudahkan pengolahan bahan baku, dan meningkatkan harga jual; dengan kandungan gizi relatif tak berubah. Kajian ini bertujuan: i) mengetahui besarnya nilai tambah produksi tepung sukun, dan ii) menganalis kelayakan usaha tepung sukun di Kepulauan Seribu, Provinsi DKI Jakarta. Data dikumpulkan melalui wawancara, observasi dan pencacatan. Nilai tambah dihitung dari pertambahan nilai produk yang diakibatkan proses pengolahan buah sukun menjadi tepung sukun; sedangkan kelayakan usaha dianalisis dari keuntungan dan R/C ratio. Usaha pengolahan tepung sukun memberikan nilai tambah, keuntungan dan $\mathrm{R} / \mathrm{C}$ ratio sebesar Rp5.500 per kilogram; Rp218 ribu; dan 1,57.

Kata kunci: nilai tambah, $\mathrm{R} / \mathrm{C}$ ratio, tepung sukun

\section{PENDAHULUAN}

Nilai tambah merupakan perbedaan nilai suatu produk sebelum dilakukan proses produksi dengan setelah dilakukan proses produksi. Peningkatan nilai tambah produk primer hasil pertanian diyakini mampu menopang peningkatan daya saing bangsa yang pada gilirannya mampu mendukung tercapainya sasaran pembangunan industri nasional (Santoso, 2008). Oleh karena itu, pengembangan agroindustri sebagai model pembangunan perekonomian hendaknya memanfaatkan sumber daya potensial daerah (Santoso, 2008).

Produk agroindustri dapat merupakan produk akhir yang siap dikonsumsi ataupun sebagai produk bahan baku industri lainnya (Soekartawi, 2000). Menurut Hicks (1995) agroindustri adalah kegiatan 
dengan ciri: i) meningkatkan nilai tambah, ii) menghasilkan produk yang dapat dipasarkan, dan iii) meningkatkan daya simpan dan pendapatan. Prospek industri pangan di Indonesia cukup cerah karena tersedianya sumber daya alam yang melimpah.

Pengembangan industri sebaiknya memanfaatkan bahan baku dalam negeri dan menghasilkan produk-produk yang memiliki nilai tambah tinggi terutama produk siap saji, praktis dan memperhatikan masalah mutu (Lukmito, 1997). Sukun merupakan salah satu tanaman potensial di Kabupaten Kepulauan Seribu, tanaman sukun di Kepulauan Seribu mencapai 1.068 pohon dengan produksi mencapai 164 kuintal.

Di Indonesia sebenarnya sukun sudah lama menjadi salah satu bahan makanan, tetapi hanya sebatas bahan pangan sekunder, seperti keripik sukun, sukun goreng, tape sukun, sukun rebus, pastel sukun, dan lain-lain. Harga buah sukun pun relatif murah, hanya Rp5.000 per buah dengan berat 1-1,5 kg; padahal sukun memiliki keunggulan untuk dijadikan sebagai salah satu alternatif bahan makanan pokok. Menurut Graham dan De Bravo (1981) buah sukun dapat diolah menjadi tepung sukun, selain itu sukun juga dapat diambil patinya (Loos et. al., 1981). Salah satu produk olahan sukun yang memiliki nilai tambah dan nilai jual tinggi adalah tepung sukun. Tepung sukun mengandung mengandung $84 \%$ karbohidrat; 9,9\% air; 2,8\% abu; 3,6\% protein dan 0,4\% lemak (BB Pascapanen, 2009).

Pengolahan sukun menjadi tepung merupakan alternatif cara pengolahan yang memiliki beberapa keunggulan, yaitu meningkatkan daya simpan, memudahkan pengolahan bahan bakunya, dan meningkatkan harga jual; dengan kandungan gizi relatif tak berubah. Tepung sukun tidak mengandung gluten sehingga tepung sukun dapat dicampur dengan tepung lain misalnya tepung beras, tepung terigu atau tepung ketan. Tepung sukun dapat mensubtitusi tepung terigu sampai $75 \%$ dalam pembuatan makanan olahan (BB Pascapanen, 2009).

Selama ini pemanfaatan sukun di Kepulauan Seribu terbatas hanya dibuat keripik sukun, sehingga sukun belum dimanfaatkan secara optimal untuk kebutuhan dan ketahahan pangan. Oleh karena itu, untuk meningkatkan motivasi petani mengolah buah sukun menjadi tepung sukun, diperlukan kajian analisis nilai tambah dan kelayakan usaha tepung sukun yang sudah dirintis di Kepulauan Seribu, Provinsi DKI Jakarta.

\section{METODE}

Kajian dilaksanakan pada bulan Mei sampai Oktober 2014 di Kepulauan Seribu, yang merupakan daerah sentra terbesar produksi buah sukun di Provinsi DKI Jakarta. Pengumpulan data dilakukan dengan metode wawancara, observasi dan pencatatan.

Nilai tambah dianalisis menggunakan metode Hayami dan Kawagoe (1993) sebagaimana disajikan pada Tabel 1. Pengukuran nilai tambah dilakukan dengan menghitung nilai tambah produk yang diakibatkan oleh pengolahan buah sukun menjadi tepung sukun. Faktor-faktor yang mempengaruhi nilai tambah untuk pengolahan dapat dikelompokan menjadi dua, yaitu faktor teknis dan faktor pasar. Faktor teknis yang berpengaruh adalah kapasitas produksi, jumlah bahan baku yang digunakan dan tenaga kerja, sedangkan faktor pasar yang berpengaruh ialah harga output, upah kerja, harga bahan baku, dan nilai input lain selain bahan baku dan tenaga kerja.

TABEL I. MODEL PERHITUNGAN NILAI TAMBAH

\begin{tabular}{|c|c|c|c|}
\hline No. & Variabel & \multicolumn{2}{|c|}{ Perhitungan } \\
\hline \multirow[t]{12}{*}{ | } & Output, Input, Harga & & \\
\hline & 1. Hasil produksi atpt(kg/produksi) & & \\
\hline & Irpatbahan baku (kg/produksi) & a & \\
\hline & Inpttenaga kerja (HOK/produksi) & $b$ & \\
\hline & Faktor konversi & C & \\
\hline & Koefisien tenaga kerja & $d$ & $=a: b$ \\
\hline & Harga produk Otpat (Rp/kg) & e & $=c: b$ \\
\hline & Upah rata-rata (Rp/HOK) & f & \\
\hline & & g & \\
\hline & Penerimaan, Pendapatan dan Nilai Tambah & & \\
\hline & 1. Harga input bahan baku (Rp/kg) & h & \\
\hline & Sumbangan inpetlain $(\mathrm{Rp} / \mathrm{kg})^{*}$ & i & \\
\hline \multirow[t]{8}{*}{ ॥ } & Nilai produk atpt(Rp/kg) & i & $=d x f$ \\
\hline & Nilai tambah (Rp/kg) & k & $=\mathrm{i}-\mathrm{h}-\mathrm{i}$ \\
\hline & Ratio nilai tambah (\%) & I & $=\mathrm{k}: \mathrm{j} \%$ \\
\hline & Pendapatan tenaga kerja $(\mathrm{Rp} / \mathrm{Kg})$ & $\mathrm{m}$ & $=\mathrm{e} \times \mathrm{g}$ \\
\hline & Bagian tenaga kerja & $n$ & $=\mathrm{m}: \mathrm{k} \%$ \\
\hline & Keuntungan $(\mathrm{Rp} / \mathrm{Kg})$ & 0 & $=\mathrm{k}-\mathrm{m}$ \\
\hline & 9. Tingkat keuntungan (\%) & p & $=0: k \%$ \\
\hline & Balas Jasa untuk Faktor Produksi & & \\
\hline \multirow[t]{4}{*}{ III } & Marjin keuntungan & $q$ & $=\mathrm{j}-\mathrm{h}$ \\
\hline & 1. Pendapatan tenaga kerja & r & $=m: q \%$ \\
\hline & Sumbangan inptlain & s & $=\mathrm{i}: \mathrm{q} \%$ \\
\hline & 3. Keuntungan perusahaan & t & $=0: q \%$ \\
\hline
\end{tabular}

Sumber: Hayami dan Kawagoe, 1993

Kelayakann usaha dianalisis dari perhitungan keuntungan, yakni pengurangan penelimaan (nilai produkni dengan biaya total (biaya tetap dan variabel); 
dan $R / C$ ratio, yakni perbandingan antara penerimaan dan biaya total.

\section{HASIL DAN PEMBAHASAN}

\section{PROSES PRODUKSI TEPUNG SUKUN}

Sukun banyak tumbuh di Kepulauan Seribu, Provinsi DKI Jakarta di antaranya di Pulau Tidung Besar dan Kecil, Pulau Payung, Pulau Pramuka, Pulau Panggang, Pulau Untung Jawa, Pulau Kelapa dan Pulau Pari. Sukun memiliki kandungan gizi yang baik, terutama sebagai sumber karhohidrat (302 kalori per 100 gr), sukun sangat potensial untuk diversifikasi pangan. Hal ini ditunjang dengan ketahanan tanaman sukun terhadap hama dan penyebaran tanaman sukun yang merata di seluruh Indonesia.

Pengolahan sukun menjadi tepung merupakan alternatif cara pengolahan yang memiliki beberapa keunggulan, namun belum banyak ditekuni masyarkat. Hal ini disebabkan terbatasnya informasi mengenai cara pengolahan dan peralatan pengolahan yang tersedia. Adapun proses pembuatan tepung sukun yang dilakukan oleh industri rumah tangga di Kepulauan seribu dapat dilihat pada Gambar 1.

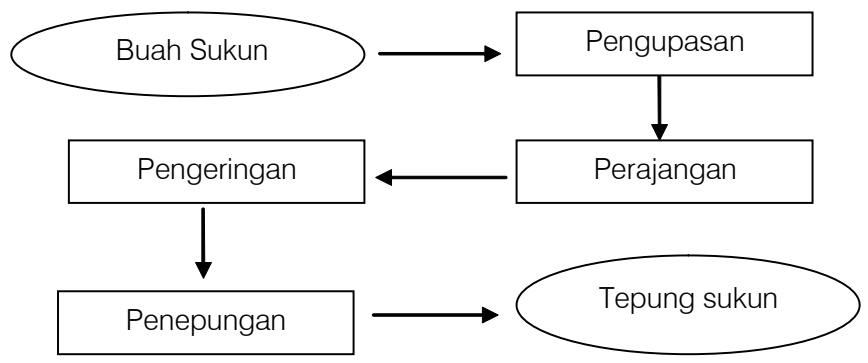

\section{GAMBAR I. DIAGRAM ALIR PROSES PRODUKSI TEPUNG SUKUN}

\section{ANALISIS NILAI TAMBAH}

Nilai tambah usaha pengolahan merupakan pengurangan antara harga barang jadi dengan biaya pengolahan dalam proses produksi. Biaya produksi ditentukan oleh biaya bahan baku, biaya penyusutan, biaya penunjang dan biaya tenaga kerja (Wilujeng et al., 2013). Kegiatan pengolahan buah sukun menjadi tepung sukun merupakan kegiatan pengubahan bentuk produk sehingga menimbulkan nilai tambah. Oleh karena itu, harga jual tepung sukun menjadi lebih tinggi dibandingkan buah sukun. Analisis nilai tambah dilakukan untuk mengetahui besarnya nilai tambah dan balas jasa terhadap faktor-faktor produksi akibat adanya kegiatan-kegiatan yang terjadi dimulai dari pengupasan buah sukun sampai menjadi tepung sukun.

TABEL 2. PERHITUNGAN ANALISIS NILAI TAMBAH BUAH SUKUN MENJADI TEPUNG SUKUN

\begin{tabular}{|c|c|c|}
\hline No & Variabel & Perhitungan \\
\hline \multirow[t]{9}{*}{ I } & \multicolumn{2}{|l|}{ Output, Input, Harga } \\
\hline & Hasil produksi atpt & 30 \\
\hline & (kg/produksi) & 50 \\
\hline & 2. Irpatbahan baku (kg/produksi) & 2 \\
\hline & 3. Inpattenaga kerja (HOK/produksi) & 0,6 \\
\hline & 4. Faktor konversi & 0,04 \\
\hline & 5. Koefisien tenaga kerja & 20.000 \\
\hline & 6. Harga produk Qtpt (Rp/kg) & 50.000 \\
\hline & \multicolumn{2}{|l|}{ Upah rata-rata (Rp/HOK) } \\
\hline \multirow{11}{*}{$\|$} & \multicolumn{2}{|l|}{ Penerimaan, Pendapatan dan Nilai } \\
\hline & Tambah & 5.000 \\
\hline & 1. Harga input bahan baku (Rp/kg) & 1.500 \\
\hline & Sumbangan irpatlain $(\mathrm{Rp} / \mathrm{kg})^{*}$ & 12.000 \\
\hline & 3. Nilai produk atpat(Rp/kg) & 5.500 \\
\hline & 4. Nilai tambah $(\mathrm{Rp} / \mathrm{kg})$ & 45,83 \\
\hline & 5. Ratio nilai tambah (\%) & 2.000 \\
\hline & Pendapatan tenaga kerja (Rp/Kg) & 36,36 \\
\hline & 7. Bagian tenaga kerja & 3.500 \\
\hline & Keuntungan (Rp/Kg) & 63,63 \\
\hline & 9. Tingkat keuntungan (\%) & \\
\hline \multirow[t]{5}{*}{ III } & \multicolumn{2}{|l|}{ Balas Jasa untuk Faktor Produksi } \\
\hline & Marjin keuntungan & 7000 \\
\hline & 1. Pendapatan tenaga kerja (\%) & 28,57 \\
\hline & 2. Sumbangan inpatlain (\%) & 21,43 \\
\hline & Keuntungan $(\%)$ & 50 \\
\hline
\end{tabular}

Setelah melakukan perhitungan nilai tambah, dilakukan pengujian nilai tambah menurut kriteria pengujian Hermawatie (1998) dalam Maulidah dan Kusumawardani (2011) yaitu: i) rasio nilai tambah rendah apabila memiliki persentase $<15 \%$; ii) rasio nilai tambah sedang apabila memiliki persentase $15 \%-40 \%$; iii) rasio nilai tambah tinggi apabila memiliki persentase $>40 \%$. Analisis nilai tambah didasarkan dari perhitungan satu kali proses produksi dengan output jumlah tepung sukun yang dihasilkan, yaitu $30 \mathrm{~kg}$; bahan baku yang dibutuhkan $50 \mathrm{~kg}$ buah sukun; dalam waktu antara 3-4 hari. Hasil analisis nilai tambah buah sukun menjadi tepung sukun dapat dilihat pada Tabel 2.

Berdasarkan perhitungan nilai tambah produksi tepung sukun (Tabel 2), tepung sukun memberikan nilai 
tambah sebesar Rp5.500 (45,83\%) per kilogram bahan baku (sukun). Besar kecilnya nilai tambah yang dihasilkan tergantung dari besarnya biaya yang dikeluarkan dan nilai produk tepung sukun. Biaya tersebut meliputi biaya pembelian bahan baku sukun $(\mathrm{Rp} / \mathrm{kg})$ dan biaya input lainya ( $\mathrm{Rp} / \mathrm{kg}$ bahan baku).

Nilai produk diperoleh dari hasil perkalian antara faktor konversi (menunjukkan besarnya perolehan produk jadi dari $1 \mathrm{~kg}$ bahan baku) dengan harga rata-rata produk per unit (Supriyati et. al., 2006). Nilai tambah yang dihasilkan ini didistribusikan pada pendapatan tenaga kerja dan keuntungan industri rumah tangga. Harga bahan baku yang digunakan dalam perhitungan nilai tambah adalah Rp5.000 per kg, sedangkan harga tepung sukun yang dihasilkan adalah Rp20.000. Hasil perhitungan menunjukkan bahwa hasil output lebih kecil dibandingkan dengan input yang digunakan, hal tersebut terjadi karena buah sukun terdiri dari bagian kulit yang tidak dapat digunakan sebagai bahan baku serta daging buah yang merupakan komponen utama untuk dijadikan tepung.

Tenaga kerja yang dibutuhkan dalam satu kali proses produksi tepung sukun mulai dari pengupasan sampai menjadi tepung sukun, sebanyak dua orang. Upah tenaga kerja sebesar Rp50.000 per hari orang kerja (HOK). Nilai koefisien tenaga kerja langsung untuk pembuatan tepung sukun adalah 0,04. Nilai ini menunjukkan bahwa untuk mengolah satu kilogram buah sukun menjadi tepung sukun diperlukan tenaga kerja sebesar 0,04 $\mathrm{HOK}$ atau setiap penambahan $100 \mathrm{~kg}$ buah sukun dibutuhkan tenaga kerja langsung sebanyak $4 \mathrm{HOK}$. Sumbangan input lain, meliputi penyusutan mesin penepung yang digunakan, bahan bakar mesin, dan kemasan yang digunakan menghabiskan dana sebesar Rp1.500. Nilai produk didapatkan dari perkalian faktor konversi dengan harga produk.

Tepung sukun memiliki nilai produk sebesar Rp12.000. Nilai ini berarti bahwa setiap pengolahan satu kilogram buah sukun akan menghasilkan nilai tepung sukun sebesar Rp12.000. Jumlah nilai produk ini menunjukkan besarnya penerimaan kotor per kilogram bahan baku buah sukun yang diolah menjadi tepung sukun. Jika nilai produk yang sudah dikalikan dengan faktor konversi dikurangi dengan nilai output dan sumbangan input lain, maka diperoleh nilai tambah sebesar Rp5.500. Nilai tersebut menyatakan bahwa setiap satu kilogram buah sukun yang diolah akan menghasilkan keuntungan sebesar Rp5.500. Apabila nilai tambah tersebut dibagi dengan nilai produk maka akan diperoleh rasio nilai sebesar tambah sebesar 45,83\% yang berari bahwa nilai tepung sukun sebesar Rp12.000, sebesar 45,83\% merupakan nilai tambah dari pengolahan produk.

\section{ANALISIS USAHA PENGOLAHAN TEPUNG SUKUN}

Analisis usahatani digunakan untuk menghitung biaya total usaha tepung sukun dalam proses pembuatannya, yang meliputi biaya tetap dan biaya variabel. Tujuan analisis usaha pengolahan tepung sukun adalah untuk menggolongkan biaya menurut fungsi pokok dalam usaha dan menurut perilakunya dalam perubahan volume kegiatan usaha. Seluruh biaya yang ada kemudian dikelompokkan menurut perilakunya dalam perubahan volume kegiatan usaha ke dalam biaya tetap dan biaya variabel dengan penjelasan sebagai berikut.

\section{Biaya tetap}

Biaya tetap usaha pengolahan tepung sukun terdapat pada biaya produksi yaitu biaya penyusutan. Biaya penyusutan pada alat-alat yang digunakan dalam proses produksi dalam hal ini adalah alat penepung. Biaya penyusutan peralatan sebenarnya tidak benarbenar dikeluarkan pada usaha pengolahan buah sukun menjadi tepung sukun tetapi karena dalam kajian ini menggunakan konsep keuntungan, maka biaya ini harus diperhitungkan. Besarnya biaya penyusutan peralatan dihitung dengan rumus: (Nilai Investasi Awal - Investasi Akhir) / umur ekonomis. Setelah dilakukan perhitungan, biaya penyusutan alat sebesar Rp16.666 per produksi.

2. Biaya variabel

Biaya variabel tediri dari biaya pembelian bahan baku utama, biaya pembelian bahan tambahan penolong dan biaya pembebanan input lain. Jenis dan besarnya biaya variabel pengolahan buah sukun menjadi tepung sukun dalam satu kali produksi adalah biaya bahan baku sebesar Rp250.000, biaya bahan penolong yaitu pembelian kemasan sebesar Rp15.000 dan biaya lain yaitu tenaga kerja sebesar Rp100.000. Total biaya variabel yang dikeluarkan untuk satu kali produksi adalah Rp365.000.

3. Biaya total

Biaya total usaha pengolahan tepung sukun meliputi 
seluruh biaya tetap dan biaya variabel. Besarnya biaya total usaha pengolahan tepung sukun dalam satu kali proses produksi dapat dilihat pada Tabel 3. Biaya yang paling besar adalah biaya variabel karena jenis biaya variabel lebih banyak dibandingkan biaya tetap. Hal ini menyebabkan biaya yang dikeluarkan untuk memenuhi kebutuhan variabel juga besar.

TABEL 3. BIAYA TOTAL PENGOLAHAN SUKUN MENJADI TEPUNG SUKUN

\begin{tabular}{lll}
\hline Jenis biaya & Jumlah (Rp/Produksi) & Persentase (\%) \\
\hline Biaya Tetap & 16.666 & 4,4 \\
Biaya Variabel & 365.000 & 95,6 \\
Biaya Total & 381.666 & 100,0 \\
\hline
\end{tabular}

\section{Penerimaan dan keuntungan}

Penerimaan usaha pengolahan sukun menjadi tepung sukun dihitung dari jumlah produksi yang dihasilkan dikalikan dengan harga. Keuntungan usaha adalah selisih antara nilai penjualan yang diterima dengan biaya yang dikeluarkan untuk memproduksi barangbarang yang dijual tersebut (Lipsey et. al., 1990). Keuntungan yang diterima dari usaha pengolahan buah sukun menjadi tepung sukun dalam satu kali proses produksi merupakan hasil perhitungan dari selisih antara penerimaan dengan biaya total. Penerimaan dan keuntungan usaha usahatani tepung sukun dapat dilihat pada Tabel 4 .

TABel 4. PENERIMAAN DAN KEUNTUNGAN PENGOLAHAN SUKUN MENJADI TEPUNG SUKUN

\begin{tabular}{ll}
\hline Uraian & Nilai \\
\hline Volume produksi (kg) & 30 \\
Harga jual per kg & 20.000 \\
Penerimaan (Rp) & 600.000 \\
Keuntungan (Rp) & 218.334 \\
\hline
\end{tabular}

5. Efisiensi usaha pengolahan buah sukun menjadi tepung sukun

Menurut Hanafi (2004), efisiensi ekonomis menyangkut perbandingan output dengan input. Dengan kata lain, suatu usaha dikatakan efisien jika mampu menghasilkan output yang lebih besar dengan menggunakan input tertentu. Salah satu indikator efisiensi adalah $R / C$ ratio (Rahardi, 1999). Efisiensi usaha pengolahan buah sukun menjadi tepung sukun dilakukan dengan menggunakan analisis perhitungan $\mathrm{R} / \mathrm{C}$ Ratio, yaitu dengan membandingkan antara penerimaan dengan total biaya. Perhitungan analisis efisiensi tersebut dapat dilihat pada Tabel 5 .

TABEL 5. R/C RATIO PENGOLAHAN BUAH SUKUN MENJADI TEPUNG SUKUN

\begin{tabular}{ll}
\hline Uraian & Nilai \\
\hline Penerimaan (TR) & 600.000 \\
Total biaya produksi (TC) & 381.666 \\
R/C Ratio & 1,57 \\
\hline
\end{tabular}

Nilai R/C rasio pada usaha pengolahan sukun menjadi tepung sukun adalah 1,57 berarti, setiap Rp100 biaya yang dikeluarkan dalam awal kegiatan usaha pengolahan sukun menjadi tepung sukun memberikan penerimaan sebesar 1,57 dari biaya yang telah dikeluarkan. Misalnya saja dalam awal kegiatan usaha pengolahan sukun menjadi tepung sukun mengeluarkan biaya $\mathrm{Rp} 100.000,00$ maka akan memperoleh penerimaan sebesar Rp157.000,00. Semakin besar R/C rasio maka akan semakin besar pula penerimaan yang akan diperoleh.

\section{KESIMPULAN}

Nilai tambah yang dihasilkan usaha pengolahan sukun menjadi tepung sukun adalah Rp5.500 per kg sukun atau 45,83\% dari nilai produksi. Keuntungan yang diterima pada usaha pengolahan sukun menjadi tepung sukun dalam satu kali proses produksi sebesar Rp218.334 dengan $\mathrm{R} / \mathrm{C}$ rasio 1,57 . Hal ini berarti bahwa usaha pengolahan sukun menjadi tepung sukun layak untuk diusahakan.

\section{DAFTAR PUSTAKA}

Balai Besar Pascapanen Pertanian. 2009. Teknologi Pengolahan Tepung Sukun dan Pemanfaatannya untuk Berbagai Produk Makanan Olahan. Balai Besar Pascapanen Pertanian, Bogor.

Graham, H. D., \& De Bravo, E. N. 1981. Composition of breadfruit. Journal of Food Science 46: 535-539.

Hanafi, M. M. 2004. Manajemen Keuangan. Fakultas Ekonomi UGM, Yogyakarta.

Hayami, Y., \& Kawagoe, T. 1993. The Agrarian Origins of Commerce and Industry (A Study of Peaseant Marketing in Indonesia). St Martins's Press.

Hicks, P. A. 1995. An overview of issues and strategies in the development of food processing industries in Asia and the Pasific. APO Simposium. Tokyo, 28 Sept-5 Okt.

Lipsey, G. R., Peter, O. S., \& Douglas, D. P. 1990. Pengantar Mikroekonomi 1 Jilid I. Terjemahan Jaka, A. W. \& Kirbrandoko. 
Erlangga, Jakarta.

Loos, P. J., Hood, L. F., \& Graham, H. D. 1981. Isolation and characterization of starch from breadfruit. Journal of Cereal Chemistry 58(4): 282-286.

Lukminto, H. 1997. Strategi industri pangan menghadapi pasar global. Majalah Pangan, 33 (IX).

Maulidah, S. \& Kusumawardani, F. 2011. Nilai tambah agroindustri belimbing manis dan optimasi output sebagai upaya peningkatan pendapatan. Agrise 9(1): 1412-1425.

Rahardi, F. 1999. Agribisnis Tanaman Buah. Penebar Swadaya, Jakarta. Singarimbun, M., \& Efendi, S. 1989. Metode Penelitian Survey. LP3ES, Jakarta.

Santoso, I. 2008. Pengantar Agroindustri. Fakultas Teknologi Pertanian Universitas Brawijaya, Malang.

Soekartawi. 2000. Pengantar Agroindustri. PT Raja Grafindo, Jakarta.

Supriyati, A., Setiyanto, E., Suryani, \& Tarigan, H. 2006. Analisis Peningkatan Nilai Tambah Melalui Pengembangan Agroindustri. Pusat Analisis Sosial Ekonomi dan Kebijakan Pertanian.

Wilujeng, W. W., Yurisinthae, E., \& Sasli, I. Analisis nilai tambah dan efisiensi usaha pengolahan jeruk siam pontianak (Citrus nobilis var. microcarpa) Gabungan Kelompok Tani Sumber Anugerah Desa Segedong Kecamatan Tebas Kabupaten Sambas. Jurnal Social Economic of Agriculture 2(1): 67-74 